\title{
The Politics of International Law - 20 Years Later
}

\author{
Martti Koskenniemi*
}

\begin{abstract}
The essay examines some of the changes in my own thinking about the politics of engaging in international law since the original publication of the article that opened the first issue of EJIL in 1990. The essay points to the change of focus from indeterminacy (to which I am as committed as ever) of legal arguments to the structural biases of international institutions. It then discusses the politics of definition, that is to say, the strategic practice of defining international situations and problems in new expert languages so as to gain control over them. It attacks the increasing 'managerialism' in the field and ends with a few reflections about the significance of the moment of the establishment of the Journal 20 years ago.
\end{abstract}

\section{From Doctrines to Institutions}

The article that opened the European Journal of International Law 20 years ago made the point about the inevitability of 'politics' in the profession of public international law. ${ }^{1}$ It did this by analysing in some detail doctrinal problems - sovereignty, sources, history, case law - familiar to all international lawyers. It was, of course, written in the vein of 'criticism'. Its style and outlook followed those of legal realism and critical legal studies, mainstream structuralism, and aspects of legal hermeneutics - but it tried to keep its methodological commitments below the surface so as to speak directly to the field. It had been inspired by a thorough-going frustration with the isolation of public international law from developments in legal theory and method and the conviction that the naïveté of the profession was anything but innocent - that it was somehow responsible for the implication of public international law in the perpetuation of the very problems that it officially claimed to alleviate. The article was not very clear about what its target was, apart from lack of professional imagination, and it left

* Arthur Goodhart Visiting Professor of Legal Science, Cambridge University; Academy Professor, University of Helsinki. Email: martti.koskenniemi@helsinki.fi.

1 Koskenniemi, ‘The Politics of International Law', 1 EJIL (1999) 1. 
quite open its own commitments, what it wanted to 'achieve' (apart from more complexity, more self-awareness within the profession). Nor did it explain what it meant by 'politics' in its title beyond the kind of issues that lawyers had always pointed to when they discussed the use of 'discretion' in the law.

The article may itself have been somewhat naïve in its assumption that the demonstration of the contradictory and inconsequential nature of legal argument, the way everything about the law deferred to contested ('political') assumptions, about the world would make the scales fall from the eyes of the professionals; that it would compel a process of self-examination that would transform the preferences of international institutions in support of 'progressive' causes. The kind of immanent critique of which it was part does not really work like that. Above all, it is powerless against the experience that legal experts may themselves fail to take the claims of determinacy and coherence all that seriously: '[o]f course we know that it is not that simple. Of course more is at work out there.' In such a case, the critical intervention only confirms what everybody already (secretly) knows - and fires back against the critic as an accusation that the latter has simply missed the boat. Moreover, drawing attention to incoherence and conflict seems to assume that international law is an intellectual discipline that would (or should) pay much regard to logical problems. That may be altogether wrong. As craft, it may simply by-pass its intellectual ambitions as an inessential. 'We deal with serious problems of peace and war, governance, and distribution. And you are worried about coherence. As if that were somehow progressive! And if coherence and determinacy are never to be attained anyway, why would your incoherence be any better than ours?' A demonstration that 'it all depends on politics' does not move one inch towards a better politics.

Now many of these problems have been discussed and highlighted in novel ways in the course of the past two decades. A new generation of lawyers has taken stock of the power and weakness of the critiques and my own responses and revisions have been published in many places, in the fullest version in the Epilogue to the 2005 edition of From Apology to Utopia and in a lecture at the London School of Economics in $2007 .^{2}$ There is today much more readiness to engage in reflection on international law's political roles, its dark and bright sides, than 20 years ago. Students with intellectual ambition are increasingly engaging with themes first laid out in the work of David Kennedy and continued by him along with many others. The directions of new work have been explored elsewhere. ${ }^{3}$ A particularly important facet of the new approaches in the field is how they deal with post-colonial themes and often come from students in

2 From Apology to Utopia. The Structure of International Legal Argument. Reissue with a New Epilogue (2005) and Koskenniemi, 'The Fate of International Law. Between Technique and Politics', 70 MLR (2007) 1. For detailed comments by readers see especially the essays in the special issue marking the publication of the new edition of From Apology in 7 German LJ (2006), issue 12.

3 See, e.g., Cass, 'Navigating the Newstream', 65 Nordic J Int'l L (1996) 341; S.R. Ratner and A.-M. Slaughter, The Methods of International Law (2004); A. Orford, International Law and its Others (2006); Koskenniemi, 'International Legal Theory and Doctrine', in Max Planck Encyclopaedia of International Law (2008), available at: www.mpepil.com. See also E. Jouannet, H. Ruiz-Fabri, and J.-M. Sorel (eds), Regards d'une nouvelle génération sur le droit international (2008) and S. Marks (ed.), International Law on the Left: Reexamining Marxist Legacies (2008). 
the Third World, even if educated in the universities of the North. In any case, it often seems that the greatest political stakes are in whether a new generation of Third World intellectuals is able to combine legal professionalism with a new strategic awareness of the limits and possibilities offered by international law for political engagement.

The article of 20 years ago dealt with the structure of international legal language. The most significant addition to the original piece is emphasis on structural bias that moves from doctrinal analysis to a discussion of institutional practices, the way in which patterns of fixed preference are formed and operate inside international institutions. A demonstration of the lack of coherence ('politics') of legal argument is only a preface to the more important point that although all the official justifications of decision-making are such that they may support contrary positions or outcomes, in practice nothing is ever that random. Competent lawyers know that the world of legal practice is actually quite predictable. As Susan Marks has recently put it, alongside the demonstration of 'false necessity' - by now a classical critical theme - what needs demonstration is 'false contingency', the idea that because the argumentative structures are open anything goes in fact. ${ }^{4}$ Recent debates of global governance and especially international law's fragmentation have well demonstrated the emergence and operation of structural bias. Through specialization - that is to say, through the creation of special regimes of knowledge and expertise in areas such as 'trade law', 'human rights law', 'environmental law', 'security law', 'international criminal law', 'European law', and so on - the world of legal practice is being sliced up in institutional projects that cater for special audiences with special interests and special ethos. The point of creating such specialized institutions is precisely to affect the outcomes that are being produced in the international world. Very little is fully random out there, as practising lawyers know very well, directing their affairs to those institutions where they can expect to receive the most sympathetic hearing.

This is why much about the search for political direction today takes the form of jurisdictional conflict, struggle between competing expert vocabularies, each equipped with a specific bias. If such regimes are bold in ambition, and able to rely on the support of some powerful sector of the political world, then they may succeed in changing the general bias in the law. For example, the rise of the bilateral investment treaty has certainly transformed the relationship between the private investor and host state from what it was 20 years ago. On a smaller scale, the effort by the International Criminal Tribunal on Former Yugoslavia in the Tadic case to hold outside states responsible for the behaviour of parties in a civil war on the basis of the overall control they exercised over the latter is another example of a (perhaps failed) effort to change in the law in support of the 1990 s project 'against impunity'. Other examples come from the re-interpretation of general legal vocabularies such as 'human rights' in terms of the preferences of new sectoral interests - say, the interests of private ownership or security. Because 'human rights', like any legal vocabulary, is intrinsically openended, what gets read into it (or out of it) is a matter of subtle interpretative strategy.

4 Marks, 'False Contingency', 61 Current Legal Problems (forthcoming, 2009). 
If a British court is able to read the indefinite detention of a person in Iraq as a human rights measure, then that decision will become part of a shifting pattern of outcomes produced by institutions having recourse to human rights vocabularies. ${ }^{5}$

More modest but not necessarily less effective is to refrain from attacks on the old bias, and argue 'only' in terms of a patterned exception. This is how novel preferences usually are consolidated. The argument is that owing to 'recent developments' in the technical, economic, political, or whatever field (typically linked with some sociological language about 'globalization'), new needs or interests have emerged that require a new treatment. The new regime - say, a regime of environmental protection or security seeks to respond to new 'challenges' not by replacing the old rule but merely by creating an 'exception' to it. Sometimes, however, the exception may gain more ground until it becomes the new rule. 'Human rights' and 'trade' have certainly behaved like that. The fact that many US law schools (and some European ones) have replaced courses on 'public international law' by courses on 'international environmental law', 'international business transactions', 'international criminal law', or 'law and globalization' suggests that the centre may have completely collapsed, its place taken by a plethora of specializations, each with its own preferred idiom, career prospects, and, of course, structural bias. This is why the most important political conflicts in the international world are often legally articulated as conflicts of jurisdiction and applicable law. Topics such as 'trade and environment', 'security and human rights', 'development and investment' give name to some such conflicts, while notions such as 'sustainable development', 'responsibility to protect', or 'human security', among a host of others, single out fragile compromises in areas where the struggle between opposing groups of experts and their preferences has not (yet) been taken to the end. They also indicate cuttingedge themes within which ambitious lawyers increasingly like to intervene for political effect. All this is based on the insight that it is anything but irrelevant to know, regardless of what the law is, which institution gets to decide - for example, whether a problem about pollution from a nuclear reprocessing plant is dealt with under a universal law of the sea regime or a regional economic integration scheme; whether the management of fishery stocks is directed to food and agricultural officials (FAO), trade experts (WTO), or conservationists (CITES); or whether the activities of military officials in conflict-zones ought to be assessed through the prism of human rights or humanitarian law. ${ }^{6}$

5 For the former example see The Queen (on the application of Hilal Abdul-Razzaq Ali Al-Jedda) v. Secretary of State for Defence, Judgment of 12 Aug. 2005, Case No. CO/3673/2005 [2005] EWHC 1809 (Admin), [2007] QB 621, at para. 104. In the same vein, see the discussion of the arguments of Australia's Attorney-General concerning counter-terrorism measures as an implementation of human rights in Carne, 'Reconstituting "Human Security" in a New Security Environment. An Australian, two Canadians and Article 3 of the Universal Declaration on Human Rights’, 25 Australian YB of Int'l L (2006) 1.

6 The first example is that of the MOX plant. For my comments on this see Koskenniemi, 'Constitutionalism, Managerialism and the Ethos of Legal Education', 1 European Journal of Legal Studies (2007) 1; for the latter see M.A. Young, 'A Legal Framework for Regime Interaction: Lessons from International Trade and Fisheries Regimes', Talk at the Lauterpacht Centre of International Law, Cambridge, 21 Nov. 2008. For a recent plea to apply human rights (over humanitarian law) standards in international conflict see Orakhelashvili, 'The Interaction between Human Rights and Humanitarian Law: Fragmentation, Conflict, Parallelism, or Convergence?', 19 EJIL (2008) 161. 
Political intervention is today often a politics of re-definition, that is to say, the strategic definition of a situation or a problem by reference to a technical idiom so as to open the door for applying the expertise related to that idiom, together with the attendant structural bias. Here, only imagination sets the limit. Think about an everyday international occurrence such as the transport of hazardous chemicals at sea. This can be conceptualized at least through half a dozen vocabularies accompanied by the same number of forms of expertise and types of preference: law of trade, law of transport, law of the environment, law of the sea, 'chemical law', and the law of human rights. Each would have something to say about the matter. Each would narrate it as part of a different set of human pursuits, values, and priorities. Trade law might focus on trade agreements between the countries and their relations with third parties. Transport law might highlight the legal-technical relationships between the different parties to a single contract of carriage and allocate jurisdiction differently between the legal systems to which they adhere. Environmental law might examine the nature of the cargo and the properties of the environment through which it is passing. Law of the sea might fix on the jurisdiction of the coastal state and the port state, or perhaps on the relevant IMO standards, while "chemical law' would examine it from the perspective of the best practices, standard operation forms, and the economic position of the industry. And, finally, the law of human rights might concentrate on the dangers of the voyage to the persons involved in it, the conditions on board the ship and during the off-loading of the cargo to the local populations. And so on. Each such vocabulary is likely to highlight some solutions, some actors, some interests. None of them is any 'truer' than the others. Each renders some aspect of the carriage visible, while pushing other aspects into the background, preferring certain ways to deal with it, at the cost of other ways. What is being put forward as significant and what gets pushed into darkness is determined by the choice of the language through which the matter is looked at, and which provides the basis for the application of a particular kind of law and legal expertise. That this choice is not usually seen as such - that is as a choice - by the vocabularies, but instead something natural, renders them ideological. If 20 years ago it seemed intellectually necessary and politically useful to demonstrate the indeterminacy (and, thus, political preference) within the idiom of public international law, today's critique will have to focus on the clash of different idioms - public international law just one competitor among many to global authority - and highlight the way their competing descriptions work to push forward some actors or interests while leaving others in the shadows.

The politics of re-definition is about shifts in the production of types of outcome within international institutions, reflecting efforts by the native language speakers of some local idiom to raise the status of that idiom to a kind of Esperanto. This is what the emphasis on 'universality' in our profession is looking after. It may not be sufficient simply to occupy the place of decision. One may also want to ensure that the decisions seem to emanate from some external logic or method that is neutral among the participants, that what is at work is not really 'one's' method but the universal (or 'scientific') method - or, even better, that at work is not a 'method' at 
all but reality itself. ${ }^{7}$ There is nothing that would be new or out of order in this process - apart from the fact that the struggles are described in the neutral language of expertise. ${ }^{8}$ This hides or obscures the contingent nature of the choices made, the fact that at issue is structural bias and not the application of some neutral economic, environmental, human rights, or security reason. To this extent the vocabularies act as 'ideologies' in the technical sense of reifying, making seem necessary or neutral something that is partial and contested. Awareness of bias in this sense suggests two conclusions in regard to teaching students, writing articles, or co-operating with colleagues. One is to examine more closely the strategic choices that are opened by particular vocabularies of global governance. The other concerns the proper attitude to take with regard to the managerialism underlying today's international legal debates.

\section{Practice: An Eye to Strategic Choices}

International law today offers a wide variety of specialist vocabularies and institutions with which we engage in legal practice. Very often, as David Kennedy has observed, we commit to them without reflecting on their effects in the world of outcomes. ${ }^{9}$ There is the sense that doing 'international law' or 'human rights' or 'free trade' or by working for institutions that are committed to 'refugees', 'humanitarian law', or 'human security' is by itself a progressive move, and that joining the native speakers of those idioms is automatically a beneficial move to accomplish. But if the critique of indeterminacy of 20 years ago is right, then that cannot be automatically the case. On the contrary, the vocabularies and institutions must themselves appear as sites of controversy and compromise where prevailing 'mainstreams' constantly clash against minority challengers. Broad agreement on institutional objectives among lawyers in the same field often leads to complete disagreement about how the objectives should be understood and what might be the best way of bringing them about in a particular situation; there is a Left and a Right of trade law as well as conservative and anticonservative ways to speak about human rights. Globalization may have shifted the locus of political engagement from 'sovereign states' to 'functional regimes' ${ }^{10}$ But it has hardly transformed the dynamics of such engagement. It is still about conquering the decision-making position within one's institution, and then laying out the agenda of reform.

It is useful to think of the 'functional regime' by analogy to the 'sovereign state' that existed once upon a time. Like the latter, regimes are characterized ideologically by

7 I have elsewhere described this in terms of the struggle for hegemony: see Koskenniemi, 'International Law and Hegemony: A Reconfiguration', 17 Cambridge Review of Int'l Affairs (2004) 197.

8 See further Kennedy, 'The Mystery of Global Governance', 1 Kormendy Lecture, Ohio Northern University, Pettit College of Law, 25 Jan. 2008, available at: www.law.harvard.edu/faculty/faculty-workshops/ kennedy.workshop.pdf.

9 D. Kennedy, The Dark Sides of Virtue. Reassessing International Humanitarianism (2005).

10 See G. Teubner and A. Fischer-Lescano, Regime-Kollisionen. Zur Fragmentierung des globalen Rechts (2006). 
solipsism and imperialism, both self-absorption and the urge to translate everything on sight into their own preferred idiom. Yet they are no 'billiard balls' but are divided as regards their point and purpose and the right strategic choices to be made in view of any particular situation as nation-states are. By now we have learned that possessing some particular national identity is indeterminate. It does not commit to particular ways of thinking or behaving, at least not unless one unreflectively assimilates in some phantasm of the 'national spirit' - something international lawyers have been by profession well buttressed against. Analogously, functional vocabularies are indeterminate, coexisting with the most varied ways of thinking and acting in the world. Economists, environmentalists, and human rights experts are just as divided among themselves as Finns, Frenchmen, or Fijians about how to understand the world and what to do with it. The regimes, institutions, and vocabularies offered to lawyers as languages to manage 'globalization' do not have automatic consequences: to join an institution or to choose a professional language is no more to close oneself in an iron cage than to be the national of Finland, France, or Fiji. The critique of 20 years ago demonstrated the indeterminacy of public international law. Today, critical analysis will have to do the same in regard to such alternative vocabularies. ${ }^{11}$ This is good news inasmuch as the prospects of a meaningful professional life are concerned: many things are open for re-definition and innovation inside the vocabularies themselves. But to take advantage of this requires adopting a more nuanced attitude to the jurisdictional conflicts and the attendant choices about distributionary effects. It is seldom self-evident what side one should take in disputes about competence: the trade idiom may be used to bind and to liberate, just as is the environmental idiom. This demands increasing sensitivity for the strategic choices.

Let me take a familiar example. Human rights activists and security experts frequently choose strategies for 'mainstreaming' to increase their influence in trade policy, government of failed states, or development co-operation. ${ }^{12}$ If the strategy is successful, the object institution will make increasing use of human rights or security language in its official documents and new administrative positions will be opened for 'human rights experts' or 'security experts'. While all of this may indeed empower human rights activists or security professionals, it is still very far from having any effect in institutional outcomes. In the first place, as I have tried to argue above, any policy may with some ingenuity be described in 'human rights' or 'security' terms owing to the openness of those terms. If the institutional outcomes are not changed, then the change of vocabulary will only end up stunning the capacity for transformation that was originally sought. But it is frequently unclear what the 'human rights preference' or the 'security

11 Nothing is easier than this, and much work has been done, for example, to show the indeterminacy of human rights, security, and environmental vocabularies - and thus to point to the political choices preferred or downplayed by those types of discourse. So far, the biases of the trade regime have been rather more assumed than rigorously demonstrated. A useful beginning is, however, Orford, 'Trade, Human Rights, and the Economy of Sacrifice', in Orford (ed.), supra note 3, especially at 166-192.

12 Two studies on such strategies with which I have been recently associated include S. Seppänen, Possibilities and Challenges of the Human-Rights Based Approach to Development (2005) and T. Pajuste, Mainstreaming Human Rights in the Context of The European Security and Defence Policy (2008). 
concern' might entail. In development projects, for example, human rights may be put forward to support private indigenous ownership but also in order to establish statesupported co-operatives. They may be invoked to attack or to support some large-scale agricultural project, depending on whether priority is put on concerns for food production or pollution prevention. And what about massive attacks on suspected 'terrorist outposts' in formally neutral countries? Do they actually limit or increase terrorism? The point is not that such questions could not be answered; only that applying some particular language may not yet bring clear directives for action. One needs to know whose understanding of 'human rights' or which notion of security ought to be preferred and, once that preference is fixed, what type of action will best support it. ${ }^{13}$

It is a familiar experience that the more activists participate in administrative management, the more they will feel the difficulty of identifying those policies that will actually support the interests they wanted to support as they started out. The openness of professional vocabularies to disputed choices will push lawyers to increasingly detailed analyses of economic efficiency, administrative appropriateness, social causality. The more pressing such questions become, however, the more legal work will become indistinguishable from the activity of those other experts, economic experts, administrative co-ordinators, sociologists, and so on. In the end the question arises whether there is (or can be) any distinct commitment to 'human rights' or 'security' or indeed 'law' - that would not be a commitment to a particular theory of economic development, fairness in distribution, or administrative appropriateness.

It is hard to see how the dangers in seeking to transform institutional reformers into mainstream administrators could be avoided without taking critical distance from 'mainstreaming' altogether. There is much to be said in favour of critical voices staying outside regular administrative procedures, as critics and watchdogs, flagging the interests and preferences of those who are not regularly represented in international institutions. This protects them from the need to make the kinds of mundane choices that administrators have to make on a routine basis and that call for a downsizing of one's preferences into pragmatic thumb-rules that are streamlined with existing practices. And yet this risks marginalization, irrelevance, or even the hubris of martyrdom and can no more be recommended in general terms than its counterpart. The choice whether to participate or not is an ever-present dilemma of any institutional politics and it cannot be resolved by a general formula. Only strategic sensitivity and the pursuit of critical distance can be recommended - qualities that are opposed to full immersion in the administrative culture in which one is called upon to work, that is, opposed to managerialism.

\section{Theory: Against Managerialism}

Since that early article, much has happened in the international legal academia. There is now a growing body of critical writing that uses the kinds of techniques that

13 Another recent study published in Helsinki makes some of these points: see P. Niemelä, The Politics of the Responsibility to Protect. Problems and Prospects (2008). 
it displayed and embodies the same kind of transformative urge, but is perhaps clearer in what it rejects and what it wants to achieve in the world. The critical project has been extended to human rights law, international criminal law, environmental law, post-conflict governance, state-building, and 'intervention', among others. New writing has sought links with new thinking in comparative law, private international law or private law tout court, law and development, as well as legal history. ${ }^{14}$ Work on institutional (instead of merely argumentative) practices of international actors (the UN, intergovernmental organizations, expert regimes and networks) has focused on the gap between promise and achievement. ${ }^{15}$ It has become common to adopt a feminist, or a third world, or post-colonial, or even a Marxian vocabulary, and thus to foreground the political commitments of the analysis. ${ }^{16}$ It is not at all alien to see legal writings peppered by anthropological, sociological, or references and insights carried over from international relations, political theory, or political economy.

But 'interdisciplinarity' often comes with a dubious politics. ${ }^{17} \mathrm{I}$ am particularly thinking of the kind of 'managerialism' that suggests that international problems problems of 'globalization' - should be resolved by developing increasingly complicated technical vocabularies for institutional policy-making. One encounters this often in the suggestion to replace international law's archaic mores by a political science-inspired language of 'governance', 'regulation', or 'legitimacy'. The managerial approach is critical of the formal aspects of the legal craft that it often sees as an obstacle for effective action. Its preference lies with informal 'regimes' and its focus is on (the fact of) 'compliance' rather than (normative) analysis of what there is to comply with. Managerialism wants to realize 'actors" (often identified as billiard-ball states) more or less unproblematic 'interests'. For it, the objectives of institutional action are given and the only remaining questions concern their manner of optimal realization. The fantasy position of the managerialist is that of holding the prince's ear - hence the anxious concern for concrete results, insistence on the policy-proposal at the end of the article. ${ }^{18}$ For the managerialist, normative questions about the ends of action or about the right order between conflicting ends appear only in the language of 'legitimacy'

14 The work is too extensive to be adequately reflected here. For some examples see, e.g., A. Riles (ed.), Rethinking the Masters of Comparative Law (2001); K. Knop, R. Michaels, and A. Riles (eds), Transdisciplinary Conflicts of Laws, 71 Law and Contemporary Problems (2008); D. Trubek and A. Santos, The New Law and Economic Development (2006); Orford, supra note 3; A. Anghie, Imperialism, Sovereignty and the Making of International Law (2004); N. Berman, Passions et ambivalences. Le colonialism, le nationalisme et le droit international (2008).

15 See, e.g., R. Wilde, International Territorial Administration. How Trusteeship and The Civilizing Mission Never Went Away (2008); Bhuta, 'Against State-Building', 15 Constellations (2008) 517.

16 See, e.g., C. Chinkin and H. Charlesworth, The Boundaries of International Law. A Feminist Analysis (2000); Anghie, supra note 14; Marks (ed.), supra note 3.

17 Not to say anything about the way it serves to strengthen disciplinary boundaries by taking them for granted and by perpetuating the disciplinary identifications of participants by casting them as 'representatives' of particular academic orientations.

18 I have discussed this in Koskenniemi, 'Constitutionalism as Mindset. Reflections on Kantian Themes about International Law and Globalization', 8 Theoretical Inquiries in Law (2007) 9. See also Koskenniemi, 'Miserable Comforters: International Relations as Natural Law', 15 European Journal of International Relations (forthcoming, 2009). 
that translates them into empirically manoeuvrable 'feelings' in the audience. ${ }^{19}$ And because behaviour is not caused by law but by 'coincidence of interest and coercion', the managerialist can only view 'interdisciplinarity' as a path to academic takeover: 'There is a more sophisticated international law literature in the international relations subfield of political science. ${ }^{20}$

The more one conceives of international law in those terms, however, the sillier it begins to look. The world's causalities are too complex, the strategic simplifications too crude. The functional 'interest' is not a solid policy datum to 'apply' but an object of interpretative controversy, stable neither in place nor in time and just as indeterminate as the 'rule' that it was to replace - although of course accompanied by a different bias, that of the policy-science elite. This is not only a problem about the anachronism of a suggested return to a time (of innocence?) before the Positivismusstreit of the 1960s and 1970s, that is to say, before the collapse of the idea that normative social science ought to be constructed through the idiolect of behavioural explanation and prediction. ${ }^{21}$ Of course, empirical and technical knowledges have their uses. They sharpen analysis and give a clearer sense of the available alternatives for action. But they have nothing at all to say that would be of normative and even less of emancipatory interest. ${ }^{22}$ And yet managerialism has its concealed normativity that privileges values and actors occupying dominant positions in international institutions and who therefore have no reason to take a critical attitude to those institutions. It solidifies the sense that questions of distribution and preference have already been decided elsewhere, so all that remain are technical questions, questions about how to smooth the prince's path.

On the other hand, the more I think about the traditional (European) jurisprudence of exegesis and the managerialism that seeks to challenge it, the more the two appear to inhabit the same conceptual space. The search for the right interpretation of a concept and the optimal derivation of a policy from some notion of 'interest' appear equally fixated to the search for a right answer, and the belief that this is accessible by technical reasoning, in the one case through interpretation, in the other by 'rational choice'. Both are equally insistent on downplaying the role of will and randomness, passion and ideology in the way the world is governed, and their own implication in it. Although both fall modestly back on the contextuality of each solution they offer, each still thinks of itself as a general theory or method. With this, they allocate decision-making powers to the native speakers of their attendant vocabularies, and thus attain subtle shifts in the pattern of institutional decision and outcome. At their best, both illuminate some participant experience of the world, and thus enable us to plan and communicate professionally within international institutions. At their worst, they obscure the way power works and make particular intellectual or social hierarchies appear as natural aspects of our lives.

19 See further Koskenniemi, 'Legitimacy, Rights and Ideology: Notes towards a Critique of the new Moral Internationalism', 7 Associations. J Legal and Social Theory (2003) 349.

20 J. Goldsmith and E. Posner, The Limits of International Law (2005), at 15.

21 For an introduction see T. Adorno (ed.), The Positivist Dispute in German Sociology (1976).

22 For another introduction see J. Habermas, Knowledge and Human Interests (1976). 
This suggests that the juxtaposition between European constitutional formalism and the 'imperial' challenge to international institutions by the US in the past years - the subject of much academic hand-wringing - may be somewhat off the mark. To believe that commitment to 'law' would be an automatically progressive choice is no less crude a directive to policy than the belief that all needs to be streamlined for the attainment of imperial preference. The question remains always: what kind of (or whose) law, and what type of (and whose) preference? Constitutionalism and empire go well together, as testified both by 19th-century European experience and today's American one. Of course, the constitutionalism put forward especially from German universities today is culturally connected with (or has a bias for) transparency and accountability that are valuable aspects of institutional lives. ${ }^{23}$ But these are no proof for becoming a facade for stasis, and the question needs always to be asked, what is included in the constitution, and what is left out (as 'private', for example, or as 'scientific'), and whom does the present constitution lift to decision-making positions. I totally approve of the political move to re-define the managerial world of international institutions through constitutional or administrative vocabularies - not because of the intrinsic worth of those vocabularies, however, but for the critical challenge they pose to today's culture of a-political expert rule, and perhaps for the appeal of the (Kantian) perfectibility that they set up as a regulative goal for human institutions. ${ }^{24}$ But law is no panacea. Problems in the 'war on terror', for example, do not emerge from the absence of 'law' or 'rights' - in fact, a huge amount of law and regulation enables and directs the activities of those implicated. ${ }^{25}$ Which means that merely by making something 'legal' or a matter of 'right' will not suffice as assurance for the beneficiality of one's choice. Would a Security Council authorization to the Iraq war really have changed the way we thought of it? Should it have done so? Again, one cannot avoid recourse to strategic choices. Or - more realistically - one cannot avoid oscillating between figuring out the right strategic choice and falling back on institutionally conventional ways of acting as proper thumb-rules about appropriate policy.

One antidote to exegesis and managerialism lies in a turn to history so visible in international law recently. This may have been inspired by a purely historiographical concern: the sense that not enough has been done to elucidate the often ambivalent role that law and lawyers have played in policy-making and conflict or that standard histories have either erred on the side of hagiography or have squeezed the world's causalities into excessively homogenous epochal narratives. New histories have tried to create a live sense that the profession is not only about limiting the use of power but enabling and facilitating the use of power. Often they have been inspired by a

23 For the politics of constitutionalism see now 'The Exercise of Public Authority by International Institutions', Special Issue of the German LJ (ed. A. von Bogdandy, R. Wolfrum, J. von Bernstorff, P. Dann, and M. Goldmann), 9 German LJ (2008) 1375. For the turn to administrative vocabularies see B. Kingbury, N. Krisch, and R.B. Stewart (eds), 'The Emergence of Global Administrative Law', 68 Law E Contemporary Problems (2005).

24 See Koskenniemi, 'Constitutionalism', supra note 18, at 33-36.

25 See D. Kennedy, Of War and Law (2006); Johns, 'Guantanamo Bay and the Annihilation of the Exception', 16 EJIL (2005) 613. 
normative concern, particularly the gut feeling that some aspect of today's policy is best understood as a washed-up version of some past pattern of privilege (typically Eurocentrism, colonialism, or the 'civilizing mission'). ${ }^{26}$ Historia magistra vitae may be a methodologically dubious basis on which to make the point about the importance of history. As a style of legal writing, however, historical narrative liberates the political imagination to move more freely in the world of alternative choices, illuminating both its false necessities and false contingencies.

\section{European Journal of International Law}

Some years ago I published an account of the establishment of the first international law journal, the Revue de droit international et la législation comparée in 1869 and the first professional international society, the Institut de droit international in 1873, as part of the European liberal entrenchment after a period of progress in Europe as clouds of the coming crisis had begun to appear on the political horizon. ${ }^{27}$ International law was born from a move to defend a liberal-internationalist project in a time of danger and opportunity. The men of 1873 knew what Lenin knew, namely that a journal is not only a collective propagator or a collective agitator but also a collective organizator. There was, I suppose, much of that also in the setting up of the European Journal of International Law in 1989 and the European Society of International Law some years thereafter. Twenty years ago, like at the end of the 19th century, lawyers animated by what the 'men of 1873' called their esprit d'internationalité responded to on-going changes in the world by a turn to intensified professionalism with modernizing ethos. ${ }^{28}$ That response would be organized from a variety of distinctive locations. In 1873 the key locations were Columbia University, Ghent, Heidelberg, and Geneva; in 1989 Florence, Munich, again Geneva, and Greenwich Village. The point was to turn a position of privilege into progressive causes (and inevitably the other way around). The European Journal has since then become one of the more interesting publications in the field and New York University has come to be regarded as the home of the world's most prestigious European law school. But it is harder to say whether that translates into political influence, or what direction that influence might have had. The fact that the Journal no longer accepts French manuscripts speaks much about the 'Europe' in its title. But meaningful political projects are not necessarily linked with a determined territorial base, a Nomos. The arguments made above in Part 2 suggest that labelling one's project under the title of 'Europe' may evoke all kinds of ambivalent cultural and political associations. It is a strategic choice that cannot be reduced to alignment with an inherent utopian ethos in that overburdened name.

26 See especially the works by Berman and Anghie, supra note 14 and, e.g., the extensively historical C. Mieville, Between Equal Rights: A Marxist Theory of International Law (2005) and E. Jouannet and H. RuizFabri, Imperialisme et droit international en Europe et aux Etats-Unis (2007).

27 M. Koskenniemi, The Gentle Civilizer of Nations. The Rise and Fall and International law 1870-1960 (2001), at 11-97.

28 Indeed, it often seemed, during and after 1989, that the international change was backwards, towards a future that should have been then. 
And yet one should bear in mind that what that choice achieves in the world cannot continuously be rethought in strategic terms. Like any name or a concept, it receives independence; it becomes an autonomous carrier of a bias and we adopt it as second nature, a home and a faith, a prison and an open door. 